DOI: $10.17516 / 1998-2836-0212$

УДК 665.632:544.47:544.344:547.52

\title{
Kinetic Features of the Process of Conversion of Propane to Aromatic Hydrocarbons
}

\author{
Ludmila N. Vosmerikova*, Anton A. Vosmerikov, \\ Yakov E. Barbashin and Alexander V. Vosmerikov \\ Institute of Petroleum Chemistry SB RAS \\ Tomsk, Russian Federation
}

Received 21.10.2020, received in revised form 07.01.2021, accepted 26.02.2021

\begin{abstract}
Kinetic features of the propane conversion into aromatic hydrocarbons over a galliumcontaining zeolite catalyst have been investigated. On the basis of the experimentally obtained kinetic dependences and the available literature data, a kinetic model of propane aromatization is proposed, which makes it possible to form various variations of chemical reaction behavior and to calculate the most probable routes of propane conversion.
\end{abstract}

Keywords: propane, galloaluminosilicate, ZSM-5 zeolite, kinetics, conversion, selectivity.

Citation: Vosmerikova L.N., Vosmerikov A.A., Barbashin Ya.E., Vosmerikov A.V. Kinetic features of the process of conversion of propane to aromatic hydrocarbons, J. Sib. Fed. Univ. Chem., 2021, 14(1), 21-29. DOI: 10.17516/1998-2836-0212

(C) Siberian Federal University. All rights reserved

This work is licensed under a Creative Commons Attribution-NonCommercial 4.0 International License (CC BY-NC 4.0).

* Corresponding author E-mail address: 1kplu@ipc.tsc.ru 


\title{
Кинетические особенности
}

процесса превращения пропана

в ароматические углеводороды

\section{Л.Н. Восмерикова, А. А. Восмериков, Я.Е. Барбашин, А. В. Восмериков Институт химии нефтии СО РАН Российская Федераиия, Томск}

\begin{abstract}
Аннотация. Проведено исследование кинетических особенностей процесса превращения пропана в ароматические углеводороды на галлийсодержащем цеолитном катализаторе. На основе экспериментально полученных кинетических зависимостей и имеющихся литературных данных предложена кинетическая модель ароматизации пропана, позволяющая сформировать различные варианты протекания химических реакций, рассчитать наиболее вероятные маршруты превращения пропана.
\end{abstract}

Ключевые слова: пропан, галлоалюмосиликат, цеолит ZSM-5, кинетика, конверсия, селективность.

Цитирование: Восмерикова, Л.Н. Кинетические особенности процесса превращения пропана в ароматические углеводороды / Л.Н. Восмерикова, А. А. Восмериков, Я.Е. Барбашин, А. В. Восмериков // Журн. Сиб. федер. ун-та. Химия, 2021, 14(1). С. 21-29. DOI: 10.17516/1998-2836-0212

\section{Introduction}

The conversion of light hydrocarbons into aromatic compounds is one of the most important catalytic reactions, both from a scientific point of view and from the point of view of the industrial implementation of this process. Aromatization of lower alkanes results in the formation of aromatic hydrocarbons (predominantly benzene, toluene, and xylenes), which are valuable feedstocks for the chemical and petrochemical industries. In addition, this reaction is of interest from the standpoint of studying the mechanism of the conversion of hydrocarbons, since the reaction involves the simultaneous participation of hydrocarbons of different classes in chemical transformations of several types on catalytic active sites of different nature. The aromatization of low molecular weight paraffinic hydrocarbons is a complex process that includes not only reactions aimed at obtaining the target product, but also a number of undesirable side reactions. Therefore, the selective carrying-out of the process of converting lower alkanes into aromatic hydrocarbons is possible only in the presence of highly selective catalysts. The published results of studies of the process of $\mathrm{C}_{2}-\mathrm{C}_{4}$ hydrocarbons aromatization prove the efficiency of used bifunctional systems. They are characterized by the presence of acid sites of the zeolite carrier and active metal-containing sites formed when introducing of dehydrating promoters into the catalyst [1-6]. However, in most papers devoted to the study of the mechanisms of reactions over high-silica zeolites, the kinetic data are not fully presented, which is caused by certain difficulties arising from attempts to determine the degree of influence of diffusion processes on the reaction rate [7-9]. For this purpose, appropriate 
investigations were carried out and the kinetic features of the propane aromatization process in the presence of a metal-containing zeolite catalyst were established.

\section{Experimental section}

A galloaluminosilicate (molar ratio $\mathrm{SiO}_{2} / \mathrm{Al}_{2} \mathrm{O}_{3}+\mathrm{Ga}_{2} \mathrm{O}_{3}=40$ ) containing $1.85 \mathrm{wt} \%$ of gallium oxide was used as a catalyst for investigation of the kinetics of the propane conversion process. The galloaluminosilicate was obtained in the course of hydrothermal synthesis by partial substitution of aluminum with gallium in the initial alumino-silica gel. Hexamethylenediamine was used as a structure-forming additive and water glass was used as a source of silicon in the course of synthesis. Aqueous solutions of nitric acid salts of aluminum and gallium served as the sources of oxides of aluminum and gallium. The synthesis of galloaluminosilicate was carried out in steel autoclaves with Teflon inserts at a temperature of $175{ }^{\circ} \mathrm{C}$ for 4 days. After crystallization was complete, the precipitate was filtered off, washed, dried, and calcined to remove organic impurities. The obtained sample was characterized by a high degree of crystallinity, contained no impurities of side phases and belonged to the ZSM-5 zeolite structural type. The zeolite was converted to the active H-form by double decationation with a $25 \%$ aqueous solution of $\mathrm{NH}_{4} \mathrm{Cl}$ followed by drying at $110{ }^{\circ} \mathrm{C}$ for $12 \mathrm{~h}$ and calcination in air at $550^{\circ} \mathrm{C}$ for $8 \mathrm{~h}$.

Catalytic experiments were carried out using a bench-type flow-through unit at atmospheric pressure, a reaction temperature of $550{ }^{\circ} \mathrm{C}$, and a volumetric feed rate of 500-5000 $\mathrm{h}^{-1}$. The catalyst in the amount of $0.5-5.0 \mathrm{~cm}^{3}$ was placed in a reactor and heated in a stream of nitrogen gas to the reaction temperature, then the nitrogen supply to the reactor was stopped and propane was passed through (purity 99.95 vol\%). The duration of the experiment was set according to the conditions of the process. The reaction products were analyzed by GLC using a Khromatek-Kristall 5000.2 chromatograph. To determine the composition of the liquid phase, a BP-1 PONA capillary column $(100 \mathrm{~m} \times 0.25 \mathrm{~mm} \times 0.5 \mu \mathrm{m})$ was used, while the composition of the gas phase was analyzed using a capillary GS-Gas-Pro $(60 \mathrm{~m} \times 0.32 \mathrm{~mm})$ and a packed Carbosieve S-II $(4 \mathrm{mx} 2 \mathrm{~mm})$ columns. To assess the catalytic activity of the sample, the degree of conversion of propane was determined, and the yield and selectivity of the formation of gaseous and liquid reaction products were also calculated.

\section{Results and Discussion}

For the purpose of experimental study and quantitative description of the process, it is important to establish the region where the reaction proceeds, since this determines the form of the kinetic equations describing it.

During heterogeneous catalytic processes, the reaction may proceed within following four regions:

- region of external diffusion. The rate of the process as a whole is determined by the rate of diffusion of reagents from the flow core to the outer surface of the catalyst grain or diffusion of products from the outer surface of the catalyst particle to the flow core of the reaction mixture;

- region of intradiffusion, when the rate is limited by the diffusion of reagents from the flow from the outer surface of the catalyst grain to its inner surface (or vice versa for the reaction products);

- region of external kinetics, when the rate of the process is limited by the chemical reaction itself on the outer surface of the catalyst grain; 
- region of intrakinetics, when the rate of the process is determined by the rate of the chemical reaction, that takes place on the inner surface of the catalyst grain. This is possible if the chemical reaction is slower than both external and internal diffusion.

Usually, the experimental conditions for the study of the catalytic properties of contacts are chosen in such a way that the transport processes would not be limiting, that is, the rate of the entire process would be determined only by the rate of the chemical reaction.

In this regard, at first, a series of experiments was carried out, when the height of the catalyst bed was varied and thus, the volumetric flow of the reaction mass was also changed in order to keep the conditioned contact time $\tau_{\mathrm{c}}$ constant according to the equation

$$
\tau_{\mathrm{c}}=\mathrm{V}_{\mathrm{c}} / \mathrm{W}_{0}
$$

where $\tau_{\mathrm{c}}$ is the conditional contact time, $\mathrm{s} ; \mathrm{V}_{\mathrm{c}}$ is the catalyst volume, $\mathrm{m}^{3}$; and $\mathrm{W}_{0}$ is the volumetric flow rate of the reaction mass, $\mathrm{m}^{3} / \mathrm{s}$.

The change or constancy of the main indicators of the aromatization process in such experiments suggests the presence or absence of external diffusion inhibition.

It is evident from the data shown in Fig. 1 that with an increase in the propane flow rate, the yield in aromatic hydrocarbons (ArH) increases to a certain level and then upon reaching this level it practically does not change with an increase in the feed rate. This indicates the progress of the process at low values of the propane flow rate (from 8.3 to $41.5 \mathrm{ml} / \mathrm{min}$ ) in the external diffusion region, while with its further increase, the process passes into the kinetic region. Therefore, in subsequent studies, the propane feed rate was selected in such a way as to remove external diffusion inhibition and to conduct the process in the kinetic region.

It is known [10] that when the rate of a chemical reaction is limited on the entire surface of the catalyst (intrakinetic region), the diffusion rate does not play a role, hence. the results of the process

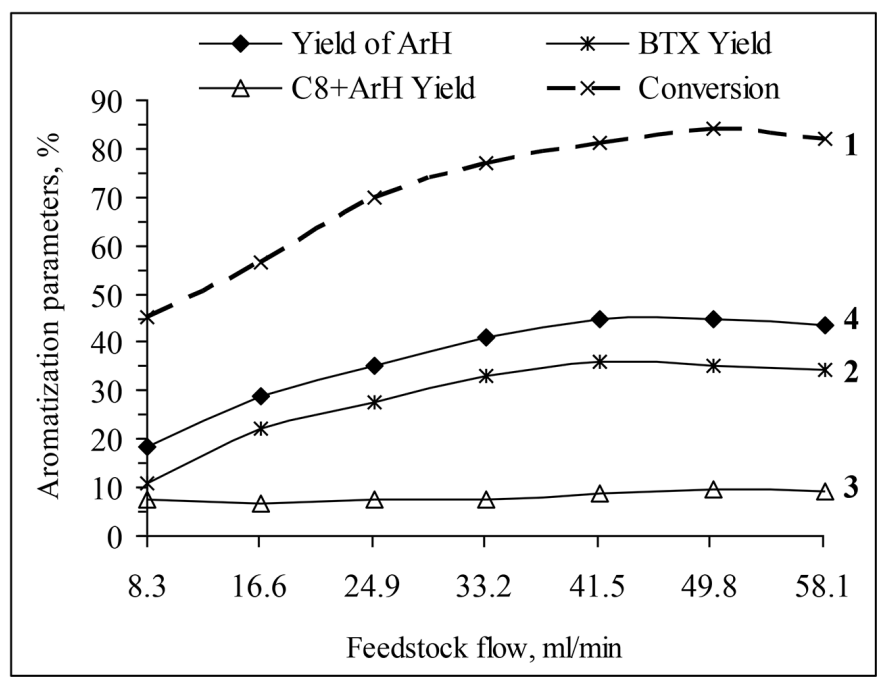

Fig. 1. Dependence of the conversion of propane (1), the yield of benzene-toluene-xylene fraction (BTX) (2), aromatic hydrocarbons of the $\mathrm{C}_{8+}$ composition (3), and the total amount of aromatic hydrocarbons (4) on the propane consumption (contact time $3.60 \mathrm{sec}$ ) 
will not depend on the catalyst grain size. On the contrary, in the case of external or internal diffusion regions, the grain size plays an important role, because the diffusion rate per unit of catalyst mass depends on the size of the outer surface, which determines the diffusion into the pores. Thus, judging by the changes in the degree of conversion in the course of a series of experiments in presence of a catalyst with different grain sizes, it is possible to distinguish the kinetic and diffusion regions and also to ascertain the catalyst grain size required to achieve the kinetic region of the process. Experiments to study the effect of the catalyst grain size on the main parameters of the propane conversion process were carried out at a contact time of $2.88 \mathrm{sec}$. The performed investigations have shown that when the process was carried out in the kinetic region, the yield in aromatic hydrocarbons was practically independent of the catalyst grain size (Fig. 2). Consequently, in this region active centers located both on the outer and inner surfaces of the catalyst operated. Since the inner surface of the zeolite prevailed over its outer surface, the process rate was not depended on the catalyst grain size.

In the presence of galloaluminosilicate, propane began to transform at a temperature of $400{ }^{\circ} \mathrm{C}$, while at $500^{\circ} \mathrm{C}$ and above, the target products were formed, which were aromatic compounds consisted mainly of benzene, toluene, and xylenes. Naphthalene, alkylnaphthalenes, and $\mathrm{C}_{9+}$ alkylbenzenes were also formed in small amounts. By-products were represented by gaseous hydrocarbons - methane and ethane. Hydrogen and $\mathrm{C}_{2}-\mathrm{C}_{4}$ olefins were also present in small amounts. Therefore, to construct the kinetic curves, catalytic tests were carried out at process temperatures of 500,550 , and $600{ }^{\circ} \mathrm{C}$ and various contact times.

Table 1 shows the results of kinetic studies obtained in the process of propane aromatization on galloaluminosilicate at different contact times and a reaction temperature of $550{ }^{\circ} \mathrm{C}$. It is seen that with increasing contact time, the degree of propane conversion and the selectivity of the formation of aromatic hydrocarbons increase. A decrease in the amount of alkanes and an increase in the amount of hydrogen are observed in the composition of gaseous products, while the concentration of alkenes passes through a maximum (Fig. 3a). The presence of methane and ethane in the products of propane

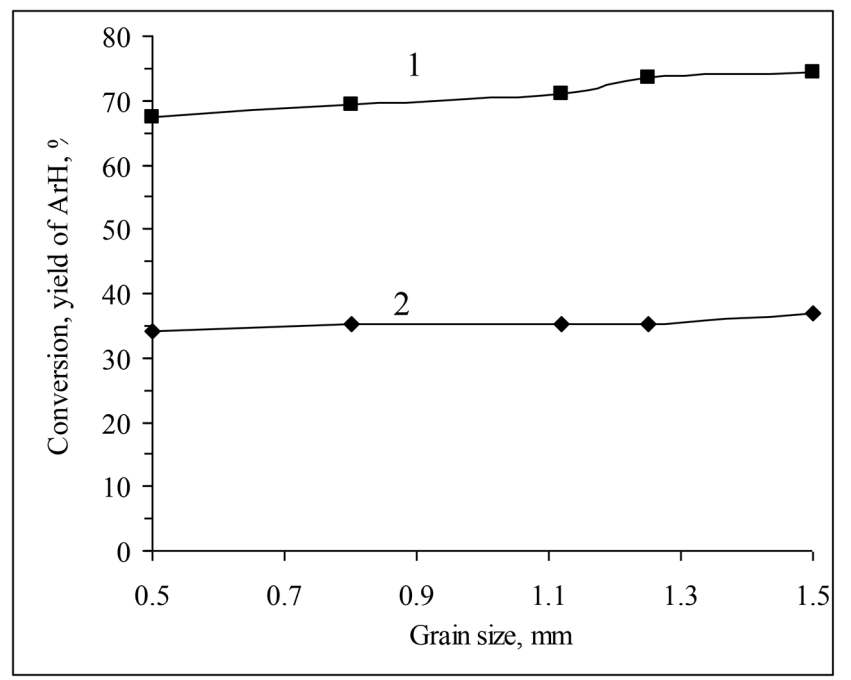

Fig. 2. Dependence of the propane conversion (1) and the ArH yield (2) on the catalyst grain size (contact time $2.88 \mathrm{sec})$ 


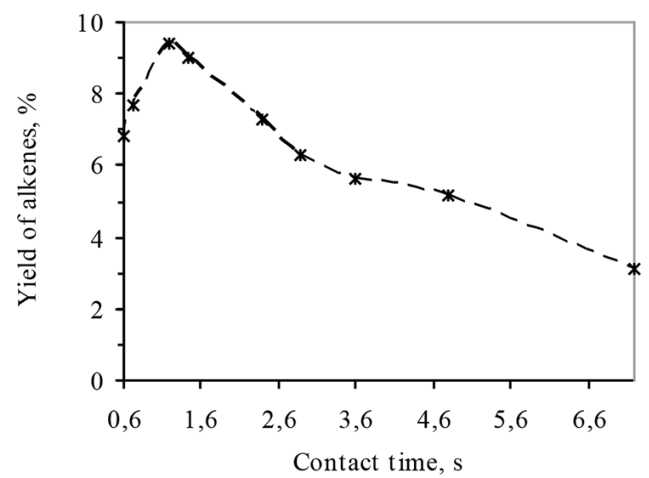

(a)

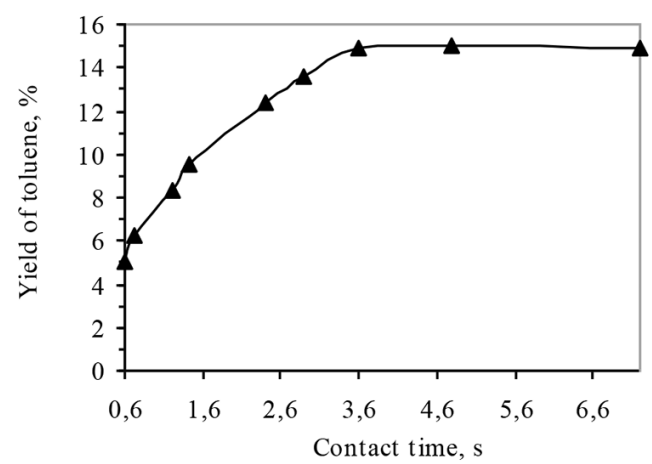

(c)

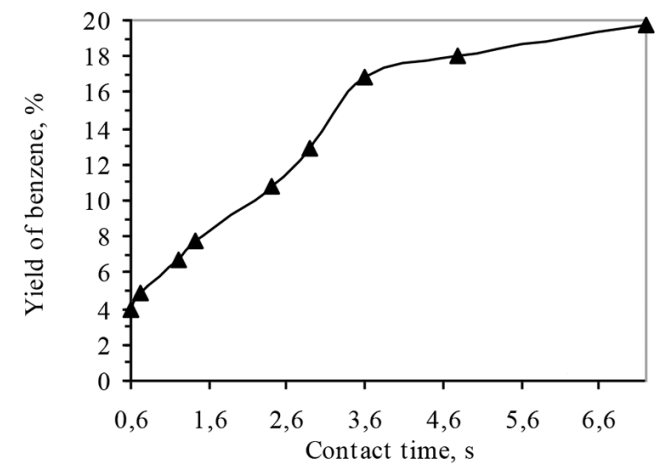

(b)

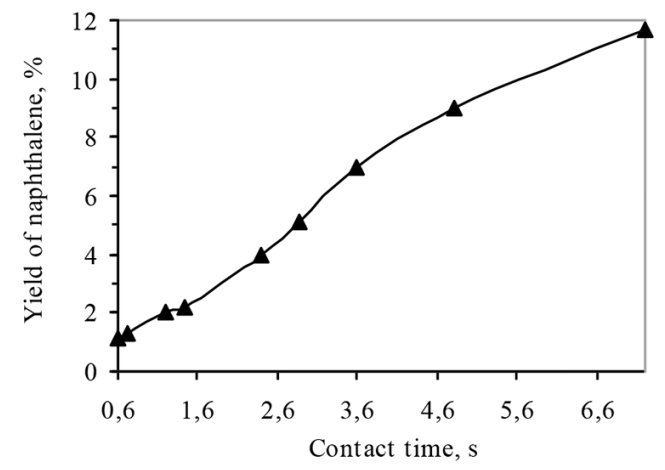

(d)

Fig. 3. Dependence of the yield in alkenes (a), benzene (b), toluene (c) and naphthalene hydrocarbons (d) formed during the conversion of propane over the galloaluminosilicate on the contact time $\left(\mathrm{T}=550{ }^{\circ} \mathrm{C}\right)$

aromatization suggests that the activation process of the initial alkane proceeds at the active sites of the galloaluminosilicate through the formation of radical cations, which further decompose to form alkene and hydrogen, or alkene and alkane with a shorter chain length. The formed alkenes undergo oligomerization, which is confirmed by the presence of a small amount of $\mathrm{C}_{4}-\mathrm{C}_{6}$ alkenes in the conversion products. A significant increase in the hydrogen concentration in the gas phase with an increase in the contact time confirms the high rate of the propane dehydrogenation reaction and the dehydrocyclization of the formed olefins over the galloaluminosilicate catalyst. This is in good agreement with the generally accepted scheme of saturated hydrocarbon aromatization, according to which the primary reactions are the dehydrogenation and cracking of paraffins, while the resulted olefins participate in secondary transformations leading to the formation of aromatic hydrocarbons [1].

Aromatic hydrocarbons were the target product of the conversion of propane to galloaluminosilicate. Studies have shown that the concentration of monoaromatic hydrocarbons (benzene and toluene) in the contact time interval from 0.60 to $3.60 \mathrm{~s}$ has increased 3-4 times, while their yield has not practically changed with a subsequent increase in the contact time (Fig. 3b, c). The content of alkylbenzenes passed through a maximum, which suggested that they underwent various transformations during the reaction (Table 1). With an increase in the contact time, the concentration of naphthalenes increased monotonically over the whole investigated time interval (Fig. 3d). Consequently, naphthalene and its homologues are not the primary reaction products, but they are formed from monocyclic aromatic 
Table 1. Composition of the products of propane conversion over galloaluminosilicate at different contact times $\left(\mathrm{T}=550{ }^{\circ} \mathrm{C}\right)$

\begin{tabular}{|c|c|c|c|c|c|c|c|c|c|}
\hline \multirow{2}{*}{ Yield of the products, wt $\%$} & \multicolumn{9}{|c|}{ Contact times, $\mathrm{s}$} \\
\hline & 0.60 & 0.72 & 1.20 & 1.44 & 2.40 & 2.88 & 3.60 & 4.80 & 7.20 \\
\hline \multicolumn{10}{|c|}{ Gaseous products } \\
\hline Hydrogen & 1.8 & 2.3 & 2.7 & 2.8 & 2.9 & 3.0 & 3.4 & 3.8 & 5.0 \\
\hline Methane & 5.6 & 7.1 & 9.1 & 10.4 & 13.6 & 16.8 & 20.7 & 21.2 & 23.6 \\
\hline Ethane & 2.6 & 3.4 & 4.3 & 5.0 & 6.7 & 7.9 & 9.6 & 10.6 & 11.6 \\
\hline $\mathrm{C}_{3}-\mathrm{C}_{4}$ alkanes & 71.1 & 64.5 & 53.4 & 48.9 & 38.2 & 28.6 & 16.1 & 12.9 & 6.5 \\
\hline $\mathrm{C}_{2}-\mathrm{C}_{4}$ alkenes & 6.8 & 7.7 & 9.4 & 9.0 & 7.3 & 6.2 & 5.5 & 5.3 & 3.1 \\
\hline \multicolumn{10}{|c|}{ Liquid products } \\
\hline Benzene & 4.0 & 4.9 & 6.7 & 7.8 & 10.5 & 12.9 & 16.9 & 18.0 & 19.7 \\
\hline Toluene & 5.0 & 6.3 & 8.3 & 9.5 & 11.8 & 13.6 & 14.9 & 15.0 & 14.9 \\
\hline Alkylbenzenes & 2.0 & 2.5 & 4.1 & 4.4 & 5.2 & 5.9 & 5.2 & 4.7 & 3.9 \\
\hline Naphthalene & 0.3 & 0.4 & 0.6 & 0.9 & 1.3 & 1.9 & 3.4 & 3.7 & 6.3 \\
\hline Alkylnaphthalenes & 0.8 & 0.9 & 1.4 & 1.3 & 2.4 & 3.2 & 4.3 & 4.8 & 5.4 \\
\hline Conversion of propane & 34 & 40 & 48 & 52 & 63 & 76 & 84 & 88 & 94 \\
\hline Selectivity towards ArH & 35.6 & 37.5 & 43.8 & 45.8 & 49.3 & 49.5 & 52.9 & 53.6 & 53.5 \\
\hline
\end{tabular}

hydrocarbons as a result of side condensation reactions, which proceed more intensively at low volumetric rates of flow or long contact times.

Based on the analysis of the mechanism of the aromatization process, the experimentally obtained kinetic dependences, and the available literature data, it is possible to form various variants of chemical reaction proceeding, on the basis of which a kinetic model could then be built:

$$
\begin{aligned}
& \mathrm{C}_{3} \mathrm{H}_{8} \longrightarrow \mathrm{C}_{3} \mathrm{H}_{6}+\mathrm{H}_{2}(\text { propylene }) \\
& \mathrm{C}_{3} \mathrm{H}_{8} \longrightarrow \mathrm{CH}_{4}+\mathrm{C}_{2} \mathrm{H}_{4}(\text { ethylene }) \\
& \mathrm{C}_{3} \mathrm{H}_{8}+\mathrm{C}_{2} \mathrm{H}_{4} \longrightarrow \mathrm{C}_{2} \mathrm{H}_{6}+\mathrm{C}_{3} \mathrm{H}_{6}(\text { propylene }) \\
& 2 \mathrm{C}_{3} \mathrm{H}_{8} \longrightarrow \mathrm{C}_{6} \mathrm{H}_{6}+5 \mathrm{H}_{2}(\text { benzene }) \\
& 2 \mathrm{C}_{3} \mathrm{H}_{6} \leftrightarrow \mathrm{C}_{6} \mathrm{H}_{6}+3 \mathrm{H}_{2}(\text { benzene }) \\
& \mathrm{CH}_{4}+\mathrm{C}_{2} \mathrm{H}_{6}+\mathrm{C}_{3} \mathrm{H}_{8} \longrightarrow \mathrm{C}_{6} \mathrm{H}_{6}+6 \mathrm{H}_{2}(\text { benzene }) \\
& 2 \mathrm{C}_{3} \mathrm{H}_{6} \longrightarrow \mathrm{C}_{2} \mathrm{H}_{4}+\mathrm{C}_{4} \mathrm{H}_{8}(\text { ethylene }+ \text { butenes }) \\
& \left.\mathrm{CH}_{4}+2 \mathrm{C}_{3} \mathrm{H}_{8} \longrightarrow \mathrm{C}_{6} \mathrm{H}_{5} \mathrm{CH}_{3}+6 \mathrm{H}_{2} \text { (toluene }\right) \\
& \left.\mathrm{C}_{3} \mathrm{H}_{6}+\mathrm{C}_{4} \mathrm{H}_{8} \longrightarrow \mathrm{C}_{6} \mathrm{H}_{5} \mathrm{CH}_{3}+3 H_{2} \text { (toluene }\right) \\
& \mathrm{CH}_{4}+3 \mathrm{C}_{3} \mathrm{H}_{8} \longrightarrow \mathrm{C}_{10} \mathrm{H}_{8}+10 \mathrm{H}_{2}(\text { naphthalene }) \\
& \mathrm{C}_{6} \mathrm{H}_{6}+\mathrm{C}_{4} \mathrm{H}_{8} \longrightarrow \mathrm{C}_{10} \mathrm{H}_{8}+3 \mathrm{H}_{2}(\text { naphthalene }) \\
& \mathrm{C}_{7} \mathrm{H}_{8}+\mathrm{C}_{3} \mathrm{H}_{6} \longrightarrow \mathrm{C}_{10} \mathrm{H}_{8}+3 \mathrm{H}_{2}(\text { naphthalene })
\end{aligned}
$$




$$
\begin{aligned}
& \mathrm{C}_{8} \mathrm{H}_{10}+\mathrm{C}_{2} \mathrm{H}_{4} \longrightarrow \mathrm{C}_{10} \mathrm{H}_{8}+3 \mathrm{H}_{2} \text { (naphthalene) } \\
& 2 \mathrm{C}_{6} \mathrm{H}_{6} \longrightarrow \mathrm{C}_{10} \mathrm{H}_{8}+\mathrm{C}_{2} \mathrm{H}_{4} \text { (naphthalene) } \\
& \mathrm{C}_{7} \mathrm{H}_{8}+\mathrm{C}_{4} \mathrm{H}_{8} \longrightarrow \mathrm{C}_{11} \mathrm{H}_{10}+3 \mathrm{H}_{2} \text { (methyl naphthalenes) } \\
& \mathrm{C}_{8} \mathrm{H}_{10}+\mathrm{C}_{3} \mathrm{H}_{6} \longrightarrow \mathrm{C}_{11} \mathrm{H}_{10}+3 \mathrm{H}_{2} \text { (methylnaphthalenes) } \\
& \mathrm{C}_{9} \mathrm{H}_{12}+\mathrm{C}_{2} \mathrm{H}_{4} \longrightarrow \mathrm{C}_{11} \mathrm{H}_{10}+3 \mathrm{H}_{2} \text { (methylnaphthalenes) } \\
& \mathrm{C}_{10} \mathrm{H}_{8}+\mathrm{C}_{2} \mathrm{H}_{6} \longrightarrow \mathrm{C}_{12} \mathrm{H}_{12}+\mathrm{H}_{2} \text { (ethyl naphthalenes) } \\
& \mathrm{C}_{11} \mathrm{H}_{10}+\mathrm{CH}_{4} \longrightarrow \mathrm{C}_{12} \mathrm{H}_{12}+\mathrm{H}_{2} \text { (dimethylnaphthalenes) } \\
& \mathrm{C}_{7} \mathrm{H}_{8}+\mathrm{H}_{2} \longrightarrow \mathrm{CH}_{4}+\mathrm{C}_{6} \mathrm{H}_{6} \text { (benzene) } \\
& \mathrm{C}_{8} \mathrm{H}_{10}+\mathrm{H}_{2} \longrightarrow \mathrm{CH}_{4}+\mathrm{C}_{7} \mathrm{H}_{8} \text { (toluene) } \\
& \mathrm{C}_{9} \mathrm{H}_{12}+\mathrm{H}_{2} \longrightarrow \mathrm{CH}_{4}+\mathrm{C}_{8} \mathrm{H}_{10} \text { (naphthalene) } \\
& \left.2 \mathrm{C}_{3} \mathrm{H}_{6} \longrightarrow \mathrm{C}_{2} \mathrm{H}_{4}+\mathrm{C}_{4} \mathrm{H}_{8} \text { (ethylene }+ \text { butenes }\right) \\
& \left.2 \mathrm{C}_{3} \mathrm{H}_{8} \longrightarrow \mathrm{C}_{2} \mathrm{H}_{6}+\mathrm{C}_{4} \mathrm{H}_{10} \text { (ethane }+ \text { butene }\right) \\
& 2 \mathrm{C}_{7} \mathrm{H}_{8} \longrightarrow \mathrm{C}_{6} \mathrm{H}_{6}+\mathrm{C}_{8} \mathrm{H}_{10}(\text { benzene }+x y \text { lene })
\end{aligned}
$$

\section{Conclusion}

Based on the experimental kinetic data, it can be assumed that the most probable route for the conversion of propane to aromatic hydrocarbons over a gallium-containing zeolite catalyst is as follows: propane $\rightarrow \mathrm{C}_{2}-\mathrm{C}_{3}$ olefins $\rightarrow \mathrm{C}_{6}-\mathrm{C}_{12}$ olefins $\rightarrow$ arenes. In addition to the main direction, the propane aromatization process is characterized by a number of sequential and parallel reactions leading to the formation of a relatively large amount of by-products such as gases and coke.

As can be seen from the above set of reactions and the suggested scheme, aromatic hydrocarbons can be formed not only due to the sequential abstraction of the hydride ion from molecules of higher molecular weight olefins (with at least six carbon atoms), but also through the direct interaction of two allylic structures with simultaneous elimination of the molecule of hydrogen. This way of formation of aromatic structures does not require the obligatory simultaneous formation of alkanes; therefore, in the case of modified zeolites, the yield in aromatic hydrocarbons is not limited by the stoichiometric ratio (one molecule of aromatic hydrocarbons plus three molecules of alkane). Obviously, this explains the higher yield in products of aromatization of low-molecular-weight paraffins over metal-containing ZSM-5 zeolites as compared to unmodified samples.

\section{Acknowledgments}

This work was carried out as part of project No. V.46.2.1 of the Program for Fundamental Scientific Research of State Academies of Sciences. 


\section{References}

1. Wan H., Pallavi C. Catalytic conversion of propane to BTX over Ga, Zn, Mo and Re impregnated ZSM-5 catalysys. J. Anal. Appl. Pyrolysis. 2016. Vol. 121, P. 369-375.

2. Zaikovskii V.I., Vosmerikova L.N., Vosmerikov A.V. Nature of the Active Centers of In-, Zr-, and Zn-Aluminosilicates of the ZSM-5 Zeolite Structural Type. Russian Journal of Physical Chemistry. 2018. Vol. 92 (4), P. 689-695.

3. Erofeev V.I., Khasanov V.V., Dzhalilova S.N., Reschetilowski W.P., Syskina A.A., Bogdankova L.A. Acidic and Catalytic Properties of Zeolites Modified by Zinc in the Conversion Process of Lower $\mathrm{C}_{3}-\mathrm{C}_{4}$ Alkanes. Catalysts. 2019. Vol. 9, P. 421.

4. Khasanova E.I., Nazmieva I.F., Ziyatdinov A.S., Salakhov I.I., Kopylov A.Y. A study of propane aromatization on a zeolite-containing catalyst with different Si/Al ratios. Petr. Chem. 2012. Vol. 52, P. 79-85.

5. Gabrienko A.A., Arzumanov S.S., Freude D., Stepanov A.G. Propane Aromatization on ZnModified Zeolite BEA Studied by Solid-State NMR in Situ. Journal of Physical Chemistry C. 2010. Vol. 114, P. 12681-12688.

6. Liu R., Zhu H., Wu Z., Qin Z., Fan W., Wang J. Aromatization of propane over Ga-modified ZSM-5 catalysts. J Fuel Chem Technol, 2015. Vol. 43(8), P. 961-969.

7. Nguyen L. H., Vazhnova T., Kolaszkowski S. T., Lukianov D. B. Combined experimental and kinetic modelling studies of the pathways of propane and n-butane aromatization over H-ZSM-5 catalyst. Chem. Eng. Sci. 2006. Vol. 61 (17), P. 5881-5894.

8. Corbetta M., Manenti F., Pirola C., Tsodikov M., Chistyakov A. Techno-economic analysis by multiscale"kinetics-to-process" simulation Aromatization of propane: Techno-economic analysis by multiscale "kinetics-to-process" simulation. Computers and Chemical Engineering 2014. Vol. 71, P. 457-466.

9. Shvets V. F., Sapunov V. N., Kozlovskii R. A., et. al. Aromatization of Propane-Butane Fraction over the ZnCrHZSM-5 Catalyst: Kinetic Modeling of the Process. Petroleum Chemistry. 2015. Vol. 55 (5), P. 632-639.

10. Лебедев Н.Н., Манаков М.Н., Швец В.Ф. Теория химических проиессов основного органического и нефтехимического синтеза. М.: Химия, 1984. 376 с. [Lebedev N.N., Manakov M.N., Shvets V.F. Theory of chemical processes of basic organic and petrochemical synthesis. Moscow, Khimiya, 1984. 376 p. (In Russ.)] 